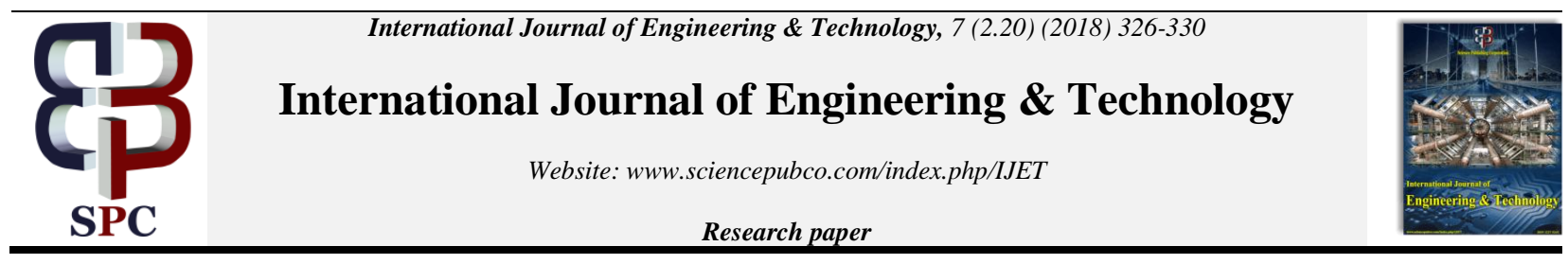

\title{
Evaluating and Implementing Strategies: Technogoly Based Financial Inclusion
}

\author{
Gowsya Shaik ${ }^{1,}$ Dr. P. Raja Babu ${ }^{2}$ \\ ${ }^{1}$ Research Scholar, KL B S, Koneru Lakshmaiah Education Foundation, Vaddeswaram, AP, India, E-Mail: gowsyashaik@kluniversity.in \\ ${ }^{2}$ Associate Professor, KL B S, Koneru Lakshmaiah Education Foundation, Vaddeswaram, AP, India, E-Mail: dr.prb@kluniversity.in
}

\begin{abstract}
:
Now a day, Financial Inclusion is delivering the banking services to the people at an reasonable price to all the huge sections for low revenue group. For achieving social benefits and objectives and also to obtain a desired economic development, RBI puts continues efforts for fulfilling the financial inclusion programme. In this direction several new initiatives were undertaken by the Government of India and it has given approval on financial inclusion plans (FIPs) for sustainable development of an economy. These are including opening bank branches, Overdraft facility for eligible accounts, transaction in Kisan Credit Cards, General Credit Card Accounts and transactions through the BCInformation Communication Technology (ICT) channel. The main objective of this research paper to know the strategy based financial inclusion and to find out the implementation and achievement of financial inclusion in India during the period of 2012-17.
\end{abstract}

Keywords: Financial Inclusion Plan, Growth rate, Economic Development

\section{Introduction:}

ion could not be fully met by the banking sector alone and there is a need for identifying innovative channels to attain inclusive growth in the country (Dr. Rao S.K). The Financial Inclusion Plan (FIP) broadly include self-set targets in respect of rural brick and mortar branches, to employ BCs (Business Correspondents), coverage of unbanked villages with a population above \& below 2,000 to open no-frills accounts including through BC-ICT (Business Correspondent using Information and Communication Technology, KCCs (Kisan Credit Cards) and GCCs (General Credit Cards), and other specific products designed by them to cater to the financially excluded segments. Thus under FIP, banks can provide its services in any selected mode to meet the needs of rural people (Shri Ranga Rajan, 2014).

\subsection{Why Need Financial Inclusion}

Financial Literacy is one of most important function of Financial Inclusion. The main important reason of financial exclusion is the lack of Knowledge about formal financial system. Financial literacy refers to the knowledge required for managing personal finance. Sarma and Pais (2010) said that literacy is positively and extensively associated with financial inclusion. To bring everyone in the nation under the ambit of financial services the government has driven Financial Inclusion. It turns savings into Investments that circular flow of income helps the economy. Investments and savings protect family against unfortunate circumstances. Income inequality falls in areas that have more developed financial intermediaries like
Financial inclusion is tool for sustainable development of an economy in the $21^{\text {st }}$ century. The challenges of financial inclus

banks, Insurance companies. In the 1980s countries that focused on provides easy financial services to small business became large economies today be it Japan, South Korea or USA. If all of government subsidy or uses of payments are done via e-transfer or net banking, then Rs 11 Lakh Crore rupee will be saved for every year in terms of manpower, time, paper work leakages-(As per MCKINSEY RESEARCH).

To obtain financial services, Access to finance is the only ability of individuals or enterprise. These are indicated as credit, deposit, payment, insurance, and other risk management services. Those who are having limited accesses to financial services are referred to unbanked or under banked respectively.

To accomplish the objectives of the organisation the main source is efficient and effective management of money (funds). Financial capability is the integration of knowledge, attitude, skills, and self-competence $\&$ it is needed to make effect money management decisions that fit the situation of one's life, within enabling the environment that includes, but is not limited to access to a good financial services.

Table 1: 012020 of Rbi For Financial Inclusion

\begin{tabular}{ll}
\hline \multicolumn{1}{c}{ Element } & \multicolumn{1}{c}{ Explanation } \\
\hline Accounts & "It is to open nearly 600 million new customer's \\
& $\begin{array}{l}\text { accounts and service them through a variety of channels } \\
\text { by leveraging on Information Technology". }\end{array}$ \\
Technology & $\begin{array}{l}\text { Finance industries to avoid of in accessibility to } \\
\text { financial services. }\end{array}$
\end{tabular}


Facilities All the households were provided with banking facilities

General Credit To issue the poor, Low income group, disadvantaged to

Card

Campaign

help them access easy credit.

A $100 \%$ financial inclusion campaign was launched by commercial banks in different regions.

Services

They are many online payments and mobile payment services to facilities like alipay and pay tm and faster financial inclusiveness.

Innovations Financial services companies have also come up with innovations to promote transparency in their dealings with customers to gain their trust.

(Sources from RBI Reports)

\section{Scope of Financial Inclusion Strategy}

- Defining financial exclusion and the new challenges that have emerge as a output of the financial crisis.

- Identifies who is most vulnerable to financial exclusion in knowsley including those newly affected by the credit crunch and recession.

- Supported by a comprehensive evidence base which will be used to highlight local issues and challenges to central government and other stakeholders.

- Establishes a number of guiding principles that will influence actions of financial inclusion

- Highlights the outcomes to achieve and how will measure progress.

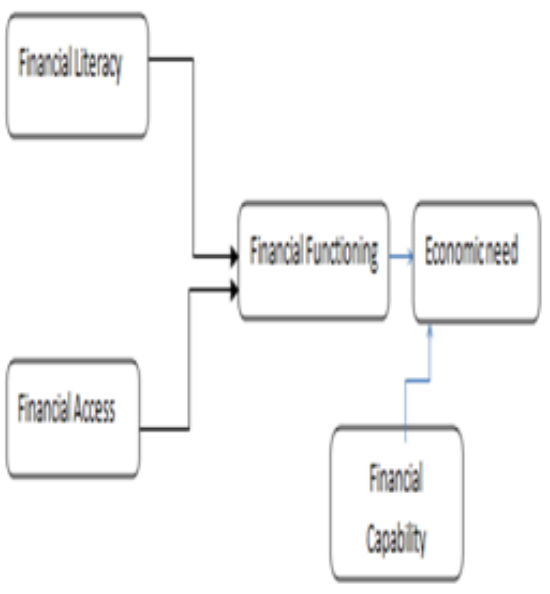

\section{Review of Literature}

1) Sadakkadulla, 2007 and Subbarao, 2010 in his article "Regional Rural Banks: Empowered Committees "has expressed Financial Inclusion has emerged as an important topic on the global agenda for sustainable long-term economic growth. It is a stepping stone and is integral to the inclusive growth process and sustainable development of the country.

2) Deutscher and Jacquet, 2009 in their article promoting Pro-Poor Growth: Employment and Social Protection highlights Inclusive growth promotes economic growth, increases standard of living, reduces poverty, decreases disparity, promotes agricultural growth rate and provides new work opportunities.

3) K.C. Chakrabarthy (2012) highlights the meaningful partnership among banks, Micro Finance Institutions and committees for promoting financial inclusion. He also opines that technology interface is not user-friendly for rural people due to lack of financial literacy. Hence, bankers' frontline staff, managers and business correspondents create friendly environment on the human side of banking.

4) Radhika Dixit and Munmun Ghosh (2013) denoted that attaining the objectives of inclusive growth is viable only through resource generation and mobilization. They argue that inclusive growth attainment depends on equitable opportunities and benefits. Financial inclusion is one of the most decisive fundamentals for complete development.

5) Dr. T. V. V. Phani Kumar (2013) says that financial literacy provides the agential capacity to an individual to select from various financial products or savings in accordance with his/her needs. The main objective of this article is to focus on the importance of financial literacy for effective financial inclusion in India and its role in disseminating its benefits to everyone in the country.

6) Basant Kumar and Brajaraj Mohanty(2011) highlights the most of the accounts that have opened as a part of the financial inclusion drive have remained inoperative due to various reasons such illiteracy, distance from the branch, lack of interest, non availability of pass books,etc.

\section{Financial Inclusion Strategy Principles}

There are five financial inclusion strategies are developed and these strategy principles will help to take actions for going forward.

- Behaviour change: The strategy will promote changes to the behaviours of individuals, organizations and financial services where it can have a positive impact.

- Prevention: provide the right tools, information and services to prevent people from becoming financially excluded.

- Sustainability: Build the skills and confidence of individuals so they are able to determine the best routes out of financial exclusion and to stay out of financial exclusion.

- Co-operation: Utilize the strengths and assets of a wide range of individuals, community groups and organizations to achieve the shared outcomes in this strategy. The strategy and action plan will also provide a means for coordinating activities and sharing best practice.

- Targeted and tailored: Through this strategy, Interventions will be targeted towards those who are most vulnerable to financial exclusion. Intervention will also be at recognized trigger points for financial exclusion and in a particular format and time that is appropriate to resident needs.

\section{Scope of the Study:}

The study focus on Kisan Credit Cards, General Purpose Credit Cards, ICT Based accounts through BCs, O.D availed in No frills accounts and its impact on GDP.

\section{Objectives of the Study}

1) To know the strategies based financial inclusion.

2) To find out the implementation and achievements of the financial inclusion

\section{Hypothesis of the Study}


- $\quad$ H0 There is no relationship between Financial Inclusion strategic variable and Growth rate.

- $\quad$ H1 There is a relationship between Financial Inclusion strategic variable and Growth rate

\section{Methodology:}

The Study is based on review of available literature and secondary data. The main data sources for the study are State Level Bankers' Committee (SLBCs) Simple Tabular forms and diagrams have been used for comparison and drawing inferences. The secondary data was collected from SLBC's it includes Kisan credit cards, General purpose credit cards, ICT Based accounts through BCs, O.D availed in No frills accounts in relation with GDP. The tools and techniques were used for data analysis.

\subsection{Strategies Measure to Achieve Financial Inclusion}

For the first time in April 2005 the term Financial Inclusion was used in India, later it was then used by Y Venugopal Reddy governor of RBI. There are several measures taken to achieve greater financial inclusion especially by the government World Bank and Reserve Bank of India. The following are the important initiated several measures to achieve greater financial inclusion.

\subsubsection{Opening BSBD (Basic Savings Bank Deposit) Accounts:}

The Reserve bank of India has advised all the banks to open a basic account with facilities such as no minimum balance, receipt or credit of money through electronic payment channels, ATM cards facilities deposit and withdrawal of cash at bank branches as well as the ATM.

\subsubsection{Kisan Credit Cards:}

The Kisan Credit Card (KCC) scheme is a credit scheme introduced in August 1998 by Indian banks. This model was prepared by the National Bank for Agriculture and Rural Development (NABARD) on the recommendations of R.V.GUPTA to provide agricultural needs and term loans.

\subsubsection{General-Purpose Credit Cards :}

It can be used to pay for just about anything - clothing at a department store, gasoline, meals at restaurants, utilities, medical services, products for sale on the Internet, as well as to get cash advances.

\subsubsection{Realization on Know Your Customer (KYC) Norms:}

To make opening of bank accounts easy, especially accounts with low balances such as not exceeding 50,000and aggregate credits in the accounts not exceeding rupees one lakh a year. Banks are also allowed to use aadhar card as proof of address and identity.

\subsubsection{Domestic Scheduled Commercial Banks (SCBs):}

These are permitted to open branches in tier- 2 to tier- 6 centres with population under one lakh under general permission subject to reporting to address the issue of uneven spread of bank branches. In north eastern states and Sikkim the domestic SCBs can open branches without permission from the RBI.

\subsubsection{Information Communication Technology(ICT):}

Bankers are to make the investments in IT based services like Management Information System, Mobile Network Operators, Technology service providers and Business correspondents model to develop efficient delivery models with the objective of effective financial inclusion delivery mechanism in order to inclusive growth of an economy.

\subsubsection{Licensing of New Banks:}

The business models aimed at furthering financial inclusion would be looked in to closely in processing applications for bank licensing. The Reserve Bank of India argued with banks to review their existing objectives and practices in order to align them with the objective of financial inclusion. It also permitted banks to use NGOs and SHGs, micro finance institutions and civil society organizations as intermediaries to facilitate financial and banking service.

\section{Financial Inclusion Policies and Strategies in India}

The recent approach and strategy based on the C.Rangarajan Committee 2008 on financial inclusion set up by the government of India, has provided more impetus to countries energetic banking system for providing timely financial services at affordable cost in the nearby to weaker sections and low income groups. Based on its recommendations the government has setup two funds with NABARD, viz., "the Financial inclusion Fund" and the "Financial Technology Fund" As per the RBI guidelines, it is envisaged that banks would need to leverage Information Communication Technology (ICT) and Smart card solution through the low cost Business Correspondent (BC) or Business Facilitator (BF) model to deliver banking in unbanked/under banked villages.

\section{Financial Inclusion Plan and its Implementations}

RBI have designed plan and financial inclusion measures to be implemented by commercial banks to provide banking services in unbanked villages. As part of the programme, all private sector and public sector banks have to prepare a three-year plan to extend their services in the identified unbanked areas.

Table 2: financial inclusion plans and achievements during the Period of 2010-16.

\begin{tabular}{|c|c|c|}
\hline YEAR & IMPLEMENTATION & ACHIEVEMENTS \\
\hline $\begin{array}{l}\text { 2010- } \\
13\end{array}$ & $\begin{array}{l}\text { During this phase I, } 74,414 \\
\text { unbanked villages with } \\
\text { population more than } 2,000 \\
\text { were identified and allotted to } \\
\text { various banks through (SLBCs) } \\
\text { State Level Bank Committees } \\
\text { for coverage through various } \\
\text { modes, i.e., branches, BCs, } \\
\text { ATMs and satellite branches, } \\
\text { etc }\end{array}$ & $\begin{array}{l}\text { A large banking network has } \\
\text { been created. } \\
\text { A large number of accounts } \\
\text { have also been opened. } \\
\text { During the first phase, nearly } \\
74,000 \text { villages with population } \\
\text { more than } 2,000 \text { were provided } \\
\text { with a banking outlet. All these } \\
\text { unbanked villages have been } \\
\text { covered by opening banking } \\
\text { outlets comprising } 2,493 \\
\text { branches, } 69,589 \text { BCs and } \\
2,332 \text { through other modes. }\end{array}$ \\
\hline $\begin{array}{l}2013- \\
16\end{array}$ & $\begin{array}{l}\text { The remaining unbanked } \\
\text { villages which in number is } \\
\text { close to } 4, \quad 90,000 \text { are } \\
\text { identified. Most of these } \\
\text { villages have a population of }\end{array}$ & $\begin{array}{l}\text { As per the progress reports } \\
\text { received from State Level Bank } \\
\text { Committees(SLBCs), banks } \\
\text { had opened banking outlets in } \\
1,83,993 \text { unbanked villages by }\end{array}$ \\
\hline
\end{tabular}


less than 2000 people. These villages are allocated to banks, for opening of banking outlets by March 2016.
March 2014, comprising 7,761 branches, 163,187 BCs and 13,045 through other modes. The Reserve Bank is closely monitoring the progress made by the banks under the roadmap.

\section{Source: Business standard 2014}

Table 3: Source: State Level Bankers' Committee (SLBCs)

\section{FINANCIAL INCLUSION STRATEGIES DURING THE PERIOD OF 2010-2017}

\begin{tabular}{|c|c|c|c|c|c|c|c|c|c|c|c|c|c|c|c|c|}
\hline$\underset{\sim}{*}$ & 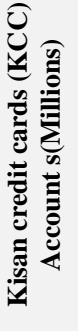 & 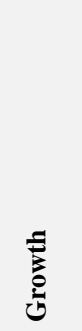 & & 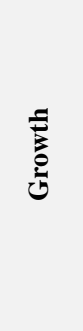 & 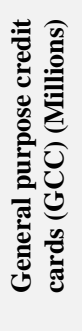 & อี & 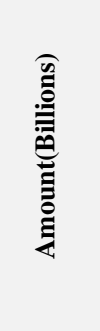 & 茪 & 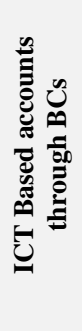 & $\overbrace{0}^{\circ}$ & 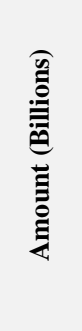 & 晃 & 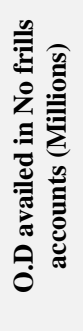 & 吾 & 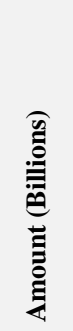 & కై \\
\hline 2010 & 15.9 & - & 940.1 & - & 0.9 & - & 35.1 & - & 12.6 & - & 12.6 & - & 0.1 & - & 0.1 & - \\
\hline 2011 & 18.2 & 14.47 & 1237 & 31.58 & 1 & 11.11 & 21.9 & -37.61 & 29.6 & -12.70 & 29.6 & 134.92 & 0.5 & 400 & 0.2 & 100 \\
\hline 2012 & 20.3 & 11.54 & 1651.5 & 33.51 & 1.3 & 30.00 & 1096.9 & 4908.68 & 52.1 & -62.84 & 52.1 & 76.01 & 1.5 & 200 & 0.6 & 200 \\
\hline 2013 & 33.8 & 66.50 & 2623 & 58.83 & 3.6 & 176.92 & 76.3 & -93.04 & 250.5 & -78.89 & 233.9 & 348.94 & 4 & 166.67 & 1.6 & 166.67 \\
\hline 2014 & 39.9 & 18.05 & 3684.5 & 40.47 & 7.4 & 105.56 & 1096.9 & 1337.61 & 328.6 & -95.61 & 524.4 & 124.20 & 5.9 & 47.5 & 16 & 900 \\
\hline 2015 & 42.5 & 6.52 & 4382.3 & 18.94 & 9.2 & 24.32 & 1301.6 & 18.66 & 477 & -96.65 & 859.8 & 63.96 & 7.6 & 28.81 & 19.9 & 24.38 \\
\hline 2016 & 47 & 10.59 & 5131 & 17.08 & 11 & 19.57 & 1493 & 14.70 & 827 & -97.69 & 1687 & 96.21 & 9 & 18.42 & 29 & 45.73 \\
\hline 2017 & 46 & -2.13 & 5805 & 13.14 & 13 & 18.18 & 2117 & 41.80 & 1159 & -98.67 & 2652 & 57.20 & 9 & 0 & 17 & -41.38 \\
\hline
\end{tabular}

The above table:03 indicates financial inclusion strategy variables are Kisan Credit Cards, General Purpose Credit Cards, ICT based accounts through Business Correspondents and Overdraft availed in no frills accounts during the year 2010-17. It is found that the growth of KCC and GCC shown the negative growth in all the years. Regarding Overdraft availed no frills account indicates highest growth rate in 2014.

Table: 04 the progress of financial inclusion plan and gdp during the period of 2012-17.

\begin{tabular}{|c|c|c|c|c|c|c|c|c|}
\hline \multirow[t]{2}{*}{ Year } & \multicolumn{2}{|c|}{ Kisan Credit Cards } & \multicolumn{2}{|c|}{ General Purpose Credit Cards } & \multicolumn{2}{|c|}{ ICT based accounts through BCs } & \multicolumn{2}{|c|}{ OD availed no frills accounts } \\
\hline & Growth & GDP & Growth & GDP & Growth & GDP & Growth & GDP \\
\hline 2012 & 11.54 & 5.46 & 30 & 5.46 & -62.84 & 5.46 & 200 & 5.46 \\
\hline 2013 & 66.5 & 6.39 & 176.92 & 6.39 & -78.89 & 6.39 & 166.67 & 6.39 \\
\hline 2014 & 18.05 & 7.51 & 105.56 & 7.51 & -95.61 & 7.51 & 47.5 & 7.51 \\
\hline 2015 & 6.52 & 8.01 & 24.32 & 8.01 & -96.65 & 8.01 & 28.81 & 8.01 \\
\hline 2016 & 10.59 & 7.11 & 19.57 & 7.11 & -97.69 & 7.11 & 18.42 & 7.11 \\
\hline 2017 & -2.13 & 6.72 & 18.18 & 6.72 & -98.67 & 6.72 & 0 & 6.72 \\
\hline
\end{tabular}

Source: State Level Bankers' Committee Report (SLBCs)

The above table presents the information on the relationship between the variables of progress of financial inclusion plan and Gross Domestic Product (GDP) during the period of 2012-17. The results of correlation between the variables are very higher for General Purpose Credit Cards than other variables. All the variables are positive correlation. Hence, alternative hypothesis will be accepted.

From the analysis its found that llnd the variables with the growth rate correlated. Hence, null hypothesis is rejected and alternate hypothesis is accepted

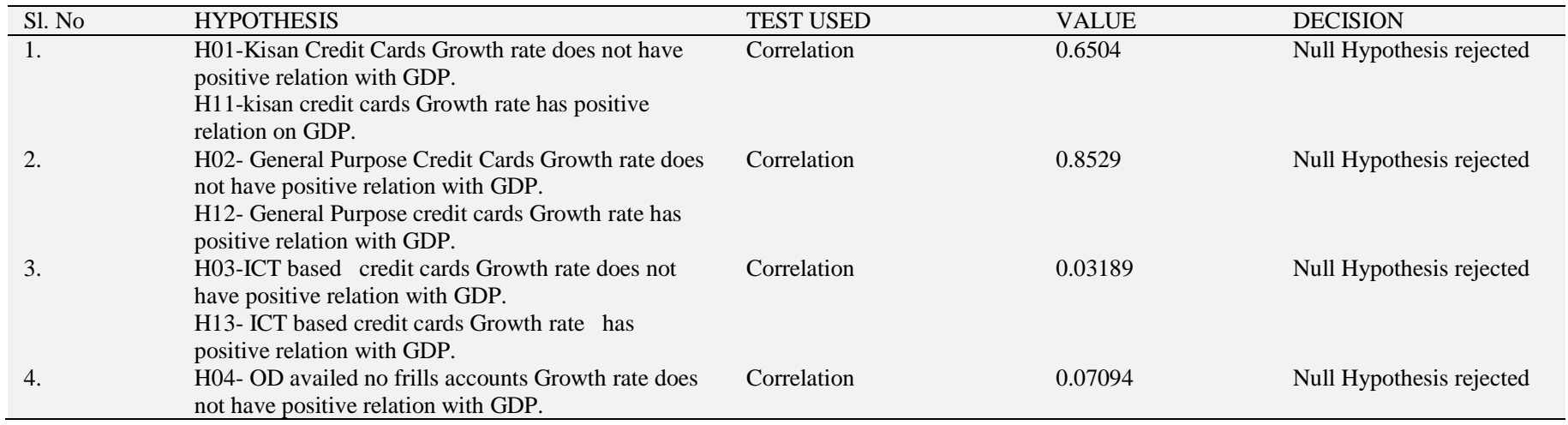




\section{Findings}

1. It is evident that 75 million households do not have access to banking services at present.

2. The government was earlier targeting $100 \%$ banking coverage but that might be difficult due to last mile connectivity. Because access to banking in areas with connectivity and infrastructure constraints will be provided in phase-II.

3. It is also observed that cores of families have mobile phones but do not have access to banking facilities.

4. The Business correspondents programme failed since the BCs were working on different technological platforms.

5. Now, Micro finance institutions and Non Banking Finance Companies (NBFCs), which are eligible to operate as BCs.

6. Today 700 million people have Aadhar; out of which 270 million have bank accounts of this only 70 million were covered in the last campaign of USA government. Hence, the government official said that there is a link with aadhar number with bank accounts.

\section{Suggestions}

It may be suggested that Branchless Banking in the form of business correspondents (Bcs) is to be further expanded because still some of villages around 50,000 villages are in forest or hilly areas. The Information Communication Technology based accounts are influencing growth rate on GDP. Honourable Finance minister Shri Arunjaitely will launch a facility to allow mobile banking on all kinds of phones. Telecom companies will expand on the line of expansion of financial services through mobile facility. Technological plat forms interoperability then we get success .for sustainable development of the economy.

\section{Conclusions}

It may conclude that Banks would target those masses who cannot afforded to visit a branch for carrying out transactions like Daily wageworkers by providing them basic banking service facilities through mobile platforms and appointing BCAs to carry out bank activities. It is also evident that technology based inclusive growth has to be influencing growth and development of an economy.

\section{References}

[1] Chakrabarthy, K. C. (5th, November,2012). Financial Inclusion- Isues in measurement and analysis Deputy Governor of the reserve bank of India,at the Bank for international Settlements . Central Bank of Malaysia Workshop on Financial Inclusion indicators .

[2] Chandran, D. (2011). Financial inclusion for strategies for inclusive growth in India.

[3] Deutscher, E. (27.9.2014). Promoting Pro poor Growth :empolyment and social Prootection relieved.

[4] Ghosh, R. D. (NMarch 2013). Financial Inclusion for Inclusive growth in India -A study of Indian States. International JOurnal of Business mangement and Research (IJBMR) , 147-156.

[5] Mohanty, B. K. (2011). Financial inclusion andinclusive development in SARRC Countries with special reference to India. Vilakshan,XIMB Journal of management .
[6] S.K, D. (July- september,pp17-24). Nationalization of Banks an anchor for financial inclusion. Bank Quest .

[7] Sadakkadulla. (n.d.). Regional Rural Banks:Empowered Committes. Cabcalling , 31(01), 15-18.

[8] Sarma, M. (18th july 2011). Financial Inclusion nad Development. Journal of International Development . 